\title{
The Impact of Fiscal Policy on Rural Economic Development in Romania
}

\author{
Sebastian Călin VAC ${ }^{1}$, Vasile Lucian NAȘ ${ }^{*^{*}}$ \\ Faculty of Horticulture, University of Agricultural Sciences and Veterinary Medicine of Cluj Napoca, 3-5 \\ Calea Mănăștur, Cluj Napoca, Romania; \\ *corresponding author, e-mail: lucian.nas@usamvcluj.ro
}

Bulletin UASVM series Agriculture 73(1) / 2016

Print ISSN 1843-5254, Electronic ISSN 1843-5394

DOI 10.15835/buasvmcn-agr: 12021

\begin{abstract}
Agriculture played a major role in the development of society since old times. The new paradigm of sustainable growth emphasizes the role of agriculture in economic growth, in ensuring food security, in poverty reduction, in the reduction of income disparities, in the development of the rural area and environmental protection. Fiscal policy is the means by which the government of a country interferes within the economy to stimulate or soothe its growth. Because the application of tax policy affects consumer demand of the society, it is considered that the fiscal policy operates on the market of goods and services units. Romanian Government's vision fiscal policy is focused on ensuring a stimulating role of taxes in order to increase the economic growth, to fiscal consolidation and to development and strengthening the middle class. The purpose of this article is to identify and highlight the impact of fiscal policy on sustainable rural economic development of Romania, in the context of Romanian rural economy realities and needs of the economic and social environment to become competitive on the European market. In order to reach our objective, we have used fundamental research methods consisting in reading of the specialized literature in this field and some articles and studies covering this topic. One of the most important decisions to make is that individual entities become legal entities with legal personality. There are necessary internal and external financing in agriculture based on investment (investment projects), involving agricultural companies and agricultural associations (not individuals bodies). Last but not least, we appreciate that the taxation of agricultural incomes is still a necessity, given the principle of universality tax, leaving it to the experts to determine the dimensions of income rules.
\end{abstract}

Keywords: tax system, agriculture, fiscal policy, rural economy, sustainable development

\section{INTRODUCTION}

Fiscal policy in Romania.

Fiscal policy is the means by which the government of a country interferes within the economy to stimulate or soothe its growth. Because the application of tax policy affects consumer demand of the society, it is considered that the fiscal policy operates on the market of goods and services units (Vorzsak and Toader, 2004).

The tools available to the government of a country to implement fiscal policy are:

- taxes - the main source of state revenues. They are paid by both individuals and legal bodies and does not involve any consideration of the State;
- government expenditure - expenses that is government doing in order to cover its consumption needs, or to restore macroeconomic balances.

Depending on the application, fiscal policy can be expansionary or restrictive.

Expansionary fiscal policy is achieved by reducing taxes or increasing government spending. Such policy support economic growth by increasing aggregate demand and creating jobs: increase household disposable income, and thus consumption demand or the state spends more. On the other hand, increased government spending has an exclusionary effect on private investment (crowding out). 
Restrictive fiscal policy is achieved by increasing taxes or reducing government expenditure. Implementation of such a policy has the effect of reducing aggregate demand: household disposable income decreases, so it reduces consumption, or reducing government consumption occurs. As a result, the economy may face an economic slowdown or even a recession.

Fiscal policy aims at the assembly of decisions modeling the fiscal system, in structural terms, and ensure its operation in order to achieve the desired aims by public managers with decisionmaking powers in this area (Corduneanu, 1998).

Equally important are the social objectives that fiscal policy aims to achieve through various activities aimed discounts, tax exemptions for certain socio-professional categories, higher taxation of destructive nature on individual businesses or products (Nuta, 2009).

Three functions of fiscal policy can be highlighted (Musgrave, 1984):

- allocation: it is established when the state must intervene in the economy to correct market failures by identifying their forms and also by efficient allocation of resources to prevent and reduce them;

- distribution: consists of all economic efficiency by stimulating the production of results in the economy, close contact solidarity action relates to those living temporarily in difficult times, fairness when individuals participating in economic life must be paid;

- stabilization: depends on the budgetary policy applied and regional development policy promoted.

Economic growth is GDP growth over a long period of time.

The channels through which taxation can affect the output growth and, by default, the economic growth are the following (Brasoveanu, 2007):

- high taxes discourage investment rate of income tax by applying individual or legal entities, by tax rate related to capital gains and lower depreciation deduction;

- taxes may lead to reduced labor supply, discouraging work or changing the decision on the accumulation of education, skill training;

- fiscal policy has the capacity to discourage increased productivity, by reducing research and development activities that can boost the productivity of capital and labor;
- by replacing investments in sectors with high taxation with lower tax sectors with lower productivity, fiscal policy can affect the marginal productivity of capital;

- large taxation on labor supply can distort efficient use of human capital by discouraging employees to work in sectors with high productivity, but too taxed.

Therefore, taxes that impact production per employee are:

- tax on salaries: although the effect would be to decrease the workload given in economy, there are factors suggesting that in some cases the income tax can increase labor supply;

- tax on capital: lead to lower savings rate and by default of investment and capital stock balance. Increased production per capita is caused by the increased savings rate;

- income taxes: the focus is on the deductibility of interest expenses. Discriminatory treatment of various forms of capital (profit, dividends, savings) can substantially decrease the rate of return on investment;

- proportional tax on consumption (value added tax): VAT does not change the relative prices of present-future consumption, so should not affect the decision to invest in physical capital.

Romanian Government's vision fiscal policy is focused on ensuring a stimulating role of taxes in order to increase the economic growth, to fiscal consolidation and to development and strengthening the middle class. Romanian Government's vision in budgetary policy is characterized by budgetary allocation efficiency on priorities based, by transparency in public spending, by ensuring the multiplier effect of public spending on the real economy. Government's fiscal policy will work in the service of tax producers rather than in the service of tax collectors, and will be based on a real partnership between the state and the taxpayer. Tax efficiency is observed both in how the taxes collected to the state budget return as the quality of public services and how they provide, in a sustainable way, maintaining and expanding tax bases (http://www.guv.ro).

\section{Rural economic development in Romania.}

According to Nemes (2005), integrated rural development is an ongoing process involving outside intervention and local aspirations; aiming to attain the betterment of groups of people 
living in rural areas and to sustain and improve rural values; through the redistribution of central resources, reducing comparative disadvantages for competition and finding new ways to reinforce and utilise rural resources.

Agriculture played a major role in the development of society since old times. The new paradigm of sustainable growth emphasizes the role of agriculture in economic growth, in ensuring food security, in poverty reduction, in the reduction of income disparities, in the development of the rural area and environmental protection (Byerlee et al., 2009).

The macroeconomic context where agriculture and rural communities developed in Romania was the result of political and strategic measures taken on short term, most of them, and included agriculture and its social area as marginal topic. Keeping marginal the rural communities and labeling them as traditional and conservatory built an obstacle in understanding a world that had its own evolution and knew how to preserve social authenticity and normality (Gavrilescu and Giurcă, 2000).

Although Romania ranks the 7th in the EU after France, Spain, Germany, Great Britain, Poland and Italy in terms of agricultural land used, there are significant discrepancies in terms of the weight of agriculture in the GDP between Romania and the EU member states, and between the incomes of the farmers, their living standards, the investment possibilities, the development prospects for agriculture. In order to fulfill its functions, agriculture must develop according to economic principles; there should be social and environmental performance, which imply efficient use of both available and attracted resources. Economic performance means efficiency in a certain system, it is not merely a comparison between effect and effort (Burja, 2011).

Since less than $8 \%$ of the population active in agriculture is under 35, given the excessive

\begin{tabular}{|c|c|c|c|c|c|c|}
\hline & \multirow{3}{*}{$\begin{array}{c}\text { Population, } \\
\text { 1 January } 2012\left(^{2}\right) \\
(1000) \\
\end{array}$} & \multicolumn{5}{|c|}{ Crude rates of change, 2011} \\
\hline & & \multirow[t]{2}{*}{$\begin{array}{c}\text { Crude rate of } \\
\text { population change (') }\end{array}$} & \multirow{2}{*}{\multicolumn{2}{|c|}{$\begin{array}{l}\text { Region with the highest population change }(d) \\
\text { (per } 1000 \text { inhabitants) }\end{array}$}} & \multicolumn{2}{|c|}{ Region with the lowest population change ( } \\
\hline & & & & & & \\
\hline EU-27(1) & 112061.9 & : & Fokida (EL245) & 19.5 & Śiauliu apskritis (LTO06) & -22.7 \\
\hline $\mathrm{BE}$ & 958.4 & 7.9 & Arr. Neufchấteau (BE344) & 14.5 & Arr. leper (BE253) & 3.5 \\
\hline BG & 2748.4 & -9.9 & Blagoevgrad (BG413) & -5.3 & Vidin (BG311) & -17.1 \\
\hline CZ & 3463.9 & -0.2 & Plzeñský kraj (CZ032) & 0.8 & Zlinský kraj (CZ072) & -1.8 \\
\hline DK & 1629.9 & -1.8 & Nordjylland (DK050) & 0.3 & Bornholm (DK014) & -11.8 \\
\hline $\mathrm{DE}$ & 13428.1 & -4.5 & Landshut, Kreisfreie Stadt (DE221) & 15.7 & Elbe-Elster (DE407) & -15.2 \\
\hline EE & 643.2 & -1.5 & Lōuna-Eesti (EE008) & -1.0 & Laảne-Eesti (EE004) & -2.2 \\
\hline IE & 3320.2 & 3.4 & Midland (IE012) & 12.2 & Border (IE011) & -4.8 \\
\hline EL & 4821.2 & -1.9 & Fokida (EL245) & 19.5 & Heia (EL233) & -8.1 \\
\hline ES & 3394.1 & -0.3 & Toledo (ES425) & 4.6 & Zamora (ES419) & -10.9 \\
\hline FR & 19524.0 & 5.3 & Haute-Corse (FR832) & 11.1 & Aube (FR212) & -1.1 \\
\hline HR & 2502.5 & -6.1 & Zadarska żupanija (HR033) & 3.9 & Ličko-senjska żupanija (HR032) & -14.7 \\
\hline Iт & 12308.4 & 0.8 & Olbia-Tempio (ITG29) & 9.1 & Oristano (ITG28) & -5.2 \\
\hline $\mathrm{CY}$ & - & - &  & & - & \\
\hline LV & 756.8 & -20.0 & Vidzeme (LV008) & -18.4 & Latgale (LV005) & -21.5 \\
\hline LT & 1265.2 & -20.1 & Telšių apskritis (LTO08) & -16.4 & Šiauliu apskritis (LTO06) & -22.7 \\
\hline LU & - & . & - & : & - & : \\
\hline HU & 4637.9 & -5.9 & Györ-Moson-Sopron (HU221) & 4.1 & Nógrád (HU313) & -14.9 \\
\hline MT & - & - & - & & - & \\
\hline NL & 106.3 & -2.4 & Zeeuwsch-Vlaanderen (NL341) & -2.4 & Zeeuwsch-Vlaanderen (NL341) & -2.4 \\
\hline AT & 3754.1 & 0.7 & Nordburgenland (AT112) & 6.9 & Unterkărnten (AT213) & -5.7 \\
\hline PL & 12838.0 & -1.3 & Nowosąeckj (PL215) & 3.7 & Łomżýski (PL344) & -5.5 \\
\hline PT & 3581.6 & -5.4 & Regiẫo Autónoma dos Açores (PT200) & 1.4 & Pinhal Interior Sul (PT166) & -13.4 \\
\hline RO & 9715.2 & -4.5 & Suceava (RO215) & -1.0 & Teleorman (RO317) & -11.6 \\
\hline SI & 899.4 & 0.6 & Notranjsko-kraškka (SI018) & 1.9 & Koroška (SI013) & -1.8 \\
\hline SK & 2721.0 & 0.8 & Prešovský kraj (SK041) & 27 & Banskobystrický kraj (SK032) & -1.3 \\
\hline $\mathbf{F I}$ & 2200.9 & 1.6 & Aland (FI200) & 12.3 & Kainuu (FI1D4) & -9.5 \\
\hline SE & 1532.7 & -0.6 & Kronobergs Ian (SE212) & 3.9 & Jamtlands län (SE322) & -3.1 \\
\hline UK & 1813.1 & 2.8 & $\begin{array}{l}\text { West and South of Northern Ireland } \\
\text { (UKN05) }\end{array}$ & 11.0 & Powys (UKL.24) & -1.8 \\
\hline IS & 116.0 & -1.1 & Landsbyggo (IS002) & -1.1 & Lands byggo (ISO02) & -1.1 \\
\hline $\mathbf{u}$ & 36.5 & 9.0 & Liechtenstein (L1000) & 9.0 & Liechtenstein (L1000) & 9.0 \\
\hline NO & 1460.4 & 7.3 & Aust-Agder (NO041) & 13.1 & Sogn og Fjordane (NO052) & 4.3 \\
\hline $\mathrm{CH}$ & 584.5 & 13.4 & Freiburg (CH022) & 21.9 & Graubünden (CH056) & 4.0 \\
\hline TR & 22706.8 & 8.3 & Bilecik (TR413) & 109.1 & Tunceli (TRB14) & -79.6 \\
\hline
\end{tabular}

1) Based on available data for Member States.

(2) Germany, Spain, the United Kingdom, Croatia and Turkey, 1 January 2011.

(2) Germany, Spain, the United Kingdom, Croatia and Turkey, 2010

(4) Excluding rural regions in Mecklenburg-Vorpommern (DE8) and Canarias (ES7); the United Kingdom, Croatia and Turkey, 2010

Source: Eurostat (online data codes: demo_r_gind3 and demo_r_d3avg)

Fig. 1. Population and population change in rural regions

Source: http://ec.europa.eu/eurostat/statistics-explained/index.php/Agriculture_-_rural_development_statistics 
fragmentation of the agricultural land (there are about 3.9 million farms), which caused more inhouse consumption and, implicitly, low profitability, the big farms of over 100 ha represent only $1 \%$ of the total of farms that own more than 1 hectare, and since most farms cultivate cereals which have the lowest productivity in the EU, it is hard to imagine that Romania could soon meet the food needs of its own citizens (Barbu, 2011).

Figure 1 shows that France had by far the largest population in predominantly rural regions, a total of 19.5 million persons as of 1 January 2012, equivalent to $17.4 \%$ of the EU-27 total. Germany, Poland, Italy and Romania had the next largest populations in predominantly rural regions and together with France these five Member States were home to $60.5 \%$ of the EU-27's population found to be living in predominantly rural regions:

In terms of agriculture and rural development fiscal policy, many authors appreciate that must be started from the need of capital injection in economic factors (investments that create jobs, which contribute to production and productivity increase on the agricultural holdings, for infrastructure development in the rural area), from the need to use the available financial resources, through funding mechanisms adequate to the present situation and whose effects should stop the economic decline and eventually generate economic growth (Otiman et al., 2010).

The first investment priority in Romania's agriculture, which must be on the first place in all the strategic programs of agriculture and rural development in Romania (funded both by internal and external resources), should be the investment in the rehabilitation and equipment of the irrigation systems, on an area of about 1.7 million ha, in the shortest time possible ( 5 years at maximum).

\section{A few recent examples around the world.}

The analysis of the fiscal policy in rural development pursued in India reveals that the system as a whole via three stage least squares, where the first stage equations predict the grants in order to deal with the simultaneities of grants received and taxation. The results show that a wage impact on taxation exists, but is very small and, the productivity impact of grants on taxes is negligible. This means that incentives effects associated with the specifics of the intergovernmental fiscal system in the states is the main determinant of village taxation (Jha et al., 2015).

In Nigeria, the problem of political instability, lack of continuity in government policies and programmes, non-implementation of programmes, improper planning, selfishness, corruption, non adherence to corporate governance, lack of transparency have been the bane of agricultural development (Kareem, 2015). In the area of capital budget implementation which adversely affect the fiscal policy of the economy and sustainable development, the following measures are recommended:

Budget funds should be tied to project requirement and funds should not be thinly spread over many project;

Government should improve on fiscal transparency by providing regular and accurate information;

The Government should initiate proper monitoring and evaluating unit with a view to ensuring proper agricultural project implementation that will have direct effect on the welfare of the citizenry.

In China, the fiscal crisis is derived from entrepreneurial governance, represented in rural areas in the early development stage as "local state corporatism" and village debt is precisely an outcome of entrepreneurial governance rather than "excessive welfare". Under entrepreneurial governance, rural collectives borrowed money from the bank for rental development as well as the provision of public services. The enterprise plays a significant role in local governance. The tight association of enterprises and the state in rural village governance is a feature of this entrepreneurial governance, while in more advanced western economies entrepreneurial governance is less directly seen as the combination of state and market but rather as public and private partnership. Therefore, to tackle the fiscal crisis, the government has to develop proper public finances beyond dependence on rental economies and using the income of rural collectives to fund public services (Desheng and Fulong, 2015).

Fiscal policy in Poland does not provide any financial support for SMEs, which forces them use other sources of financing favouring their competitiveness (Zuzek, 2010). Investigations conducted by the Market Research Agency "Opinia" have pointed to the areas, which should 
be changed, improved or adjusted to the needs of enterprises. It would allow offering the opportunities for going out of stagnation. The elements most affecting this process are the following: tax cuts $(71.4 \%)$, too high costs of labour and social security (60\%), and improved terms of credits for companies (53\%) (Agencja Badań Rynku "Opinia", 2008, apud Zuzek, 2010). The author appreciate that one of the most important measure to take is continuity and permanency of financial, state fiscal and investment policy ensuring competitiveness on domestic and international markets for ecologically pure products manufactured using more modern technologies.

Low tax collection effectiveness and an extensive VAT gap seems to be the most serious issues for tax administration in Slovakia. The number of tax inspections is the highest in Romania, together with the Czech Republic. In the case of Slovakia, tax administration problems and tax inspection are below the average of selected European countries (Orviska, 2014). Based on the results of the regressions, the authors appreciate that rural firms are more involved in the shadow economy, because perceptions of competing against informal sector firms is the highest in this case. Despite this fact, the tax inspections seem to be slightly less common in these firms in the EU. The quality of the institution seems to be one of the determinants of tax evasion. From this point of view ensuring the quality of the tax administration is a crucial factor in the fight against tax evasion. Based on a comparison among selected countries, the authors expect that the main challenges for tax administration in Slovakia are mostly the improving of tax collection efficiency and reducing the VAT tax gap. The time to prepare and pay taxes is very extensive in Romania, Ukraine and Moldova. In their oppinion, Slovakia is significantly below the average of selected countries for this indicator and this should be positive for taxpayers but could be partly responsible for the higher costs of tax administration in Slovakia. The high level of the VAT gap in Romania and Latvia could be partially the consequence of a disproportionally low share of tax administration stuff devoted to tax verification compared to other countries. Finally, the authors appreciate that these issues should be further researched by regression analysis to shed more light on this problem. Corruption in tax administration is likely to drop sharply in recent years in all of the selected countries, which is a very positive trend in the fight against tax evasion.

The LEADER (Liaisons Entre Actions de Developpement de l'Economie Rurale) community initiative is based on the principles of endogenous development and neo-endogenous development, the most important of which are: the bottomup approach, participation in decision-making, public-private partnerships, inter-territorial cooperation and networks, integrated rural development, the most effective use of local assets and resources, the promotion of innovation and economic diversification. In its first three iterations, LEADER was delivered through autonomous local action groups (LAGs) that were generally constituted as cross-sectoral partnerships and which directly engaged local people in managing and implementing rural development projects in their territories. Since 2007, however, LEADER has been integrated with other rural development measures in Pillar 2 of the Common Agricultural Policy through regional rural development plans, a significant change that has contributed to the dilution of the participatory and bottomup principles underpinning LEADER's original philosophy. From its outset in 1991, LEADER has been identified with a shift in rural development strategy from top-down, state-led modernisation programmes to a new paradigm of endogenous rural development in which rural communities determine their own development trajectories through the optimum use of local resources (Ray 1998; van der Ploeg et al. 2000).

A study realised in two regions - in Spain (Andalusia) and the UK (Wales) - revealed that even in the earlier phases LAG managers had to contend with obstacles such as bureaucracy and the excessive involvement of local authorities (Navarro et al, 2016). The authors appreciate about the managers and their colleagues in LAGs that the competing pressures of central bureaucracy and local accountability have been skillfully negotiated to produce tangible social and economic benefits for rural areas. The result was a dialogue and process of hybridisation between old and new in rural areas: old and new inhabitants, old and new economies and old and new ways of planning and making decisions. 


\section{The aim of the paper.}

The purpose of this article is to identify and highlight the impact of fiscal policy on sustainable rural economic development of Romania, in the context of Romanian rural economy realities and needs of the economic and social environment to become competitive on the European market.

\section{MATERIALS AND METHODS}

In order to reach our objective, we have used fundamental research methods consisting in reading of the specialized literature in this field and some articles and studies covering this topic.

In order to establish and analyse the state and the performance of the Romanian rural economy development in the European context and from the historical perspective, we have used the data provided by the National Institute of Statistics Romania, Institute of Social Economy, European Commission or World Bank Organization and by national statistics and by various national and international publications that we assessed and interpreted. Our methods have been: analysis, synthesis, comparison, deduction and induction.

\section{RESULTS AND DISCUSSION}

I. In terms of dimension and structure, as well as functionality, the Romanian rural area has a major importance for the national territory.

According to the World Bank data (http://data. worldbank.org/indicator/), the main agriculture indicators evolution in Romania is detailed in Tabel 1, representing $46 \%$ in total population of Romania.

The active population in agriculture represents about $30 \%$ of the country's active population (http://data.worldbank.org/indicator/SL.AGR. EMPL.ZS/countries).

Considerating the data in Tabel 1, we have to accept that agriculture and rural development must be the backbone of the romanian rural economy. No rural development program (internal or external) can be designed without agriculture having an essential role. All the strategies and programs for agriculture have the sustainable rural development as the base principle, as sustainable economic growth factor. This means a strong rural economy, based on a modern rural infrastructure, adequate technical utilities of the rural territory, rational use of renewable natural resources in the economic flow, natural environment and landscape protection and as a result, acceptable rural living standard, comparable to that in the EU.

The rural development of rural areas, both from the economic and social, habitat and cultural (conservation of traditional cultural values) point of view, presupposes, first of all, the development of economic activities, increase in the quality of working and living conditions, by the access to facilities similar to the urban areas, thus creating the necessary conditions for maintaining the population, mainly the young population, in the rural areas.

One of the first investment priority in Romania's agriculture, which must be on the first place in all the strategic programs of agriculture and rural development in Romania (funded both by internal and external resources), should be the investment in the rehabilitation and equipment of the irrigation systems.

II. According to NISR, the average size of farms in the EU-27 is 14.3 ha and in Romania is 3.45 ha, working 1,86 persons/farm. The utilized agricultural area which returned on average per farm without legal personality was 1.95 ha, compared with 1.73 ha in 2002 . The agriculture area returned an average farm with legal personality was 190.78 ha, compared to 274.43 ha in 2002.

By association, according to Law 36/1991, Law 566/2004, the agricultural societies and other forms of association in agriculture, were

Tab. 1. The agriculture evolution in Romania

\begin{tabular}{ccccc}
\hline Indicator/Year & 2010 & 2011 & 2012 & 2013 \\
\hline Number of population & $9,348,183$ & $9,275,922$ & $9,208,443$ & $9,144,468$ \\
\hline \% of population (\%) & 46 & 46 & 46 & 46 \\
\hline Agriculture land (ha) & 61.5 & 60.7 & 59.7 & 60.4 \\
\hline Agricultural irrigation land (\%) & 0.6 & 0.7 & 1.2 & 1.3 \\
\hline Agriculture GDP (\%) & 6.4 & 7.3 & 5.3 & 6.2 \\
\hline Source: http://data.worldbank.org/indicator/ & & & &
\end{tabular}


constituted by landowners, associative units family associations and agricultural associations with legal personality (agricultural societies). Owners may constitute remember and businesses under Law 3l/1990 (there are different types of such companies, are the most numerous type of limited liability companies). These companies are the result of the event entrepreneurship in agriculture. The entrepreneur has the initiative, assume certain risks, that's right, and has calculated some motivation.

The number of small farms, who used an agricultural area up to 1 ha, decreased in 2010 compared to 2002 by about 150,000 farms (6.9\%), they continued to hold an important share of around $54 \%$ of all agricultural holdings with a utilized agricultural area. Family farms (households) are numerically predominant (over 4 million) and in terms of total area and other resources owned, and most are not legal entities, but individual entities. Unfortunately, these entities without legal personality are fully not subject to taxation and does not really help to Romania's fiscal budget. Therefore, from this perspective, one of the most important decisions to make is that individual entities become legal entities with legal personality.

According to AM NRDP (2013), the association in agriculture remains limited, manufacturers are still faced with problems of information, mentality, but also overtaxation and management. In the period $2000-2010$, there is a tendency to increase agricultural associations, however, their share remains small, with regional variability. About 150 agricultural cooperatives registered nationally, active especially in the South East $(20.4 \%)$. This number is considerably lower than in other countries: while in Holland the degree of organization is $100 \%$ and the EU average is $34 \%$, in Romania degree of organization of producers is extremely low, less than $1 \%$.

The reasons are both social - with reference to the former agricultural cooperatives and distrust among rural households - and financial investment in a context of very limited resources for farmers and additional costs related to the registration and operation of a cooperative (accounting, VAT etc.). Membership is very low agricultural cooperatives, associations and cooperatives covering only $13.2 \%$ of the total arable land in 2010 , decreasing to $15.7 \%$ recorded in the 2002 Agricultural Census (www.ies.org.ro).

It appears so the strong need for counseling and advice on the operation of associative forms plus access to capital and taxation. In a first step, it needs community facilitation; bringing together farmers gives them the opportunity to discuss the problems faced in their work and identify potential solutions. The next step involves a process of coagulation of the group, working in association definition, identifying the legal form of association with the analysis of the implications arising from the legal form, a plan of organizational development and business plan.

III. For the EU countries with developed agriculture, the new Common Agricultural Policy - Health Check fits like a glove, but for Romania's agriculture this is not the case: the funds that reach the farmers by the single area payment scheme (SAPS), of about $160 €$ / arable ha (direct payments from the EU budget + complementary payments from the national budget), i.e. $720 \mathrm{RON} /$ ha (at the current exchange rate), in the case of noncommercial (subsistence and semi-subsistence) agricultural holdings, covering more than 60\% of the country's total agricultural area, are rather used as an allocation for farmers, in the best case as necessary funds for covering a minimum part of the yearly production costs. These amounts are largely used as "social protection", for covering certain expenses that are absolutely necessary for the rural households.

In our opinion, there are necessary internal and external financing in agriculture based on investment (investment projects), involving agricultural companies and agricultural associations (not individuals bodies). For the national economy, this approach has obvious benefits for agriculture financing:

- carries out all activities (both investment and agricultural) in a legal regime, fiscal and monetary controllable, avoiding tax evasion;

- increase the level of responsibility of those involved;

- further funding possibilities are diverse, creating multiplier effect in national economy;

- can achieve a higher level of food quality control;

- creates multiple possibilities for collaboration with other related industries, but also the direction of value chains in agriculture. 
IV. Since 1 February 2013, by Government Ordinance $8 / 2013$, tax is levied on income from agricultural activities, income standards based on income from land cultivation, animal breeding and exploiting held under any title, including those leased, regardless whether or not evidence recovery products. Until this date, farm incomes were not taxed. However, the current tax sets a series of income rules, allowing semisubsistence farms and subsistence not to pay any tax. We appreciate that the taxation of agricultural incomes is still a necessity, given the principle of universality tax, leaving it to the experts to determine the dimensions of income rules.

According to GEO 6/2015, starting June 1, 2015, the Government dropped all basic food VAT from $24 \%$ to $9 \%$. For this decrease in VAT on food will benefit the entire population, but most will feel the Romans with modest incomes, where food represents the largest share of expenditure. We appreciate that for the middle class might have been best measure to general VAT decrease to $20 \%$, which would have given a boost and long use goods market, services market, auto market etc.

Probably lower prices to the end consumer will not be maximal. Food prices should fall by $12.1 \%$ - but less where raw material (fuel, fertilizers etc.) is still taxed at standard rate. But manufacturers and retailers will be able to increase profit margins and to inject additional resources in their businesses either investment or new hires or revenue increases for employees.

Advisor to Prime Minister on macroeconomic issues estimated that reducing VAT on food will contribute $9 \%$ and increase potential growth by boosting consumption and investment "VAT reduction measure will help to increase potential growth (from 3\% to 4\% 2015) by boosting consumption and investment and boost - along with tax exemption on reinvested profit, reduced by 5 percent and social security contributions schemes minimis aid and SME - creating new jobs, improve the collection and will reduce tax evasion. "In his opinion, will be the by default stimulus for consumption and offer greater and more competitive food and drinks, "throwing a hand far agrifood sector, a strategic sector for Romania" (http://agrointel.ro/32437/cine-pierde-si-cinecastiga-din-reducerea-tva-la-alimente/).

\section{CONCLUSION}

The entities without legal personality in Romania are fully not subject to taxation and does not really help to Romania's fiscal budget. Therefore, from this perspective, one of the most important decisions to make is that individual entities becomelegal entities with legal personality.

The funds that reach the farmers by the single area payment scheme (SAPS), in the case of noncommercial (subsistence and semi-subsistence) agricultural holdings, covering more than 60\% of the country's total agricultural area, are rather used as an allocation for farmers, in the best case as necessary funds for covering a minimum part of the yearly production costs. These amounts are largely used as "social protection". There are necessary internal and external financing in agriculture based on investment (investment projects), involving agricultural companies and agricultural associations (not individuals bodies).

One of the first investment priority in Romania's agriculture, which must be on the first place in all the strategic programs of agriculture and rural development in Romania (funded both by internal and external resources), should be the investment in the rehabilitation and equipment of the irrigation systems.

Also, we expect that one of the successful policies in terms of sustainable development of the rural economy in the European Union to overcome the inconveniences caused by an inadequate tax system, could be the continuing implementation of Leader initiative and any other form of association and cooperation between farmers.

Last but not least, we appreciate that the taxation of agricultural incomes is still a necessity, given the principle of universality tax, leaving it to the experts to determine the dimensions of income rules.

\section{ABREVIATIONS}

AM NRDP - Managing Authority for the National Rural Development Programme

EU - European Union

GEO - Government Emergency Ordinance

GDP - Gross Domestic Product

LAG - Local action groups

NISR - National Institute of Statistics Romania

SME - Small and Medium Enterprise

VAT - Value Added Tax 


\section{REFERENCES}

1. Barbu CM (2011). The romanian agriculture - between myth and reality. Annales Universitatis Apulensis Series Oeconomica, 13(2): 485-496.

2. Brasoveanu OL (2007). The impact of fiscal policy on economic growth. ASE, Bucuresti, Romania.

3. Burja V (2011). Regional disparities of agricultural performance in Romania. Annales Universitatis Apulensis Series Oeconomica. 13 (1): 115-121.

4. Byerlee D, de Janvry A, Sadoulet E (2009). Agriculture for Development: Toward a New Paradigm. Annual Review of Resource Economics. 1: 15-31.

5. Corduneanu C, (1998). The fiscal system in finance science. CODECS, Bucuresti, Romania.

6. Desheng X, Fulong W (2015). Failing entrepreneurial governance: From economic crisis to fiscal crisis in the city of Dongguan, China. Cities - The International Journal of Urban Policy and Planning. 43: 10-17.

7. Gavrilescu D, Giurcă D (2000). Agrifood Economics. Expert Publishing House in co-edition with Biotera Publishing House, Bucharest, 360.

8. Jha R, Nagarajan HK, Tagat A, (2015). Restricted and Unrestricted Fiscal Grants and Tax Effort of Rural Local Governments in India. ASARC Working Paper 2015/01, research program on „Building Policy Research Capacity for Rural Governance and Growth in India"

9. Kareem RO (2015). Agricultural Development and Political Economy: A Review of the Nigerian Experience. Scholars Journal of Economics, Business and Management. 2(1B): 80-90.

10. Musgrave RA, Musgrave PB (1984). Public Finance in Theory and Practice. McGraw Hill Book, New York.

11. Navarro FA, Woods M, Cejudo E (2016). The LEADER Initiative has been a Victim of Its Own Success. The Decline of the Bottom-Up Approach in Rural Development Programmes. The Cases of Wales and Andalusia. Sociologia Ruralis, 56 (2): 270-288.

12. Nemes G (2005). Integrated rural development - the concept and its operation. Institute of Economics Hungarian Academy of Sciences, Budapest, Hungary.

13. Nuta A, Nuta F, (2009). Fiscal and budgetary policies and mechanisms. Europlus, Galati, Romania.

14. Orviska M, Hunady . (2014). Selected Challenges of Tax Administration in the Context of Fiscal Consolidation in
European countries. 8th International Conference on Currency, Banking and International Finance: The Role of Financial Sector in Supporting the Economic Recovery of CEE Countries, Bratislava, Slovakia, 287-301.

15. Otiman PI, Toderoiu F, Florian V, Alexandri C, Gavrilescu C, Ionel I, Grodea M, Alboiu C, Moldovan M, Goşa V, Nagy A (2010). Agriculture and rural development in Romania - the main modalities to attenuate the crisis effects and to resume economic growth. Agricultural Economics and Rural Development, 7 (2): 163-211.

16. van der Ploeg JD, Renting H, Brunor G (2000). Rural development: from practices and policies towards theory. Sociologia Ruralis 40(4): 391-408.

17. Ray C (1998). New places and space for rural development in the European Union: an analysis of the UK Leader II Programme. Working Paper 34 pp. 1-51.

18. Vorzsak M, Toader V (2004). Macroeconomics. AlmaMater, Cluj-Napoca, Romania.

19. Zuzek DK (2010). Small and Medium-sized Enterprises versus Rural Development in the View of Sustainable Development. Economic Science for Rural Development. 23: 51-55.

20. *** National Institute of Statistics Romania (NISR): General Agricultural Census 2010, http://www.insse.ro/ cms/files/RGA2010/.

21. *** Ministry of Agriculture and Rural Development, Managing Authority for the National Rural Development Programme (AM NRDP), 2013. Socio-economic analysis in light of rural development 2014-2020.

22. *** Institute of Social Economy, www.ies.org.ro.

23. *** Law 36/1991 - on agricultural societies and other forms of association in agriculture.

24. *** Law 31/1990 - on commercial companies.

25. *** Law 566/2004 - Agricultural cooperatives Law, as amended and supplemented.

26. *** Government Ordinance 8/2013 - Change the Fiscal Code and regulation of financial and tax measures.

27. *** World Bank Organization, www.worldbank.org.

28. *** Government Emergency Ordinance (GEO) no. 6 of 7 April 2015 amending and supplementing Law no. $571 / 2003$ regarding the Fiscal Code.

29. *** The Romanian Government, http://www.guv.ro. 